\title{
Knowledge, Attitude and Practice Related to the Pap Smear Test Among Users of a Primary Health Unit ${ }^{1}$
}

\author{
Camila Teixeira Moreira Vasconcelos ${ }^{2}$ \\ Ana Karina Bezerra Pinheiro ${ }^{3}$ \\ Ana Rita Pimentel Castelo ${ }^{4}$ \\ Lillian de Queiroz Costa ${ }^{4}$ \\ Roberta Grangeiro de Oliveira ${ }^{4}$
}

This KAP (knowledge, attitude and practice) study, carried out from February to June 2008, aimed to evaluate the knowledge, attitude and practice regarding the Pap smear test among users of a primary health unit (PHU) and to verify any association with sociodemographic variables. The sample was comprised of 250 women. The knowledge, attitude and practice related to the examination were adequate in $40.4 \%, 28 \%$ and $67.6 \%$ of respondents, respectively. The results demonstrate higher proportions of adequate knowledge and attitude with schooling ( $>9$ years) and age ( $>35$ years). It is essential to seek specific answers regarding this issue in order to direct integrated actions of health education, thus ensuring greater access, adhesion and return of the women for the examination results.

Descriptors: Health Knowledge, Attitudes, Practice; Vaginal Smears; Uterine Cervical Neoplasms; Nursing. \footnotetext{
camilamoreiravasco@hotmail.com.

Corresponding Author:

Ana Karina Bezerra Pinheiro

Universidade Federal do Ceará

Rua: Alexandre Baraúna, 1115

Bairro Rodolfo Teófilo

CEP: 60430-160 - Fortaleza, CE, Brasil

E-mail: anakarinaufc@hotmail.com
}

${ }^{1}$ Supported by CNPq, process \# 620117/2008-7 and 471673/2008-0.

2 RN, Doctoral Student in Nursing, Universidade Federal do Ceará, CE, Brazil. Scholarship holder CAPES/PROPAG. E-mail:

${ }^{3}$ RN, Ph.D. in Nursing, Professor, Universidade Federal do Ceará, CE, Brazil. E-mail:anakarinaufc@hotmail.com.br.

${ }^{4}$ Nursing undergraduate student, Universidade Federal do Ceará, CE, Brazil. E-mail: Ana Rita - anaritacastelo@hotmail.com, Lilian - lillianqueiroz@hotmail.com, Roberta - roberta_grangeiro@hotmail.com. 


\title{
Conhecimento, atitude e prática relacionada ao exame colpocitológico entre usuárias de uma unidade básica de saúde
}

Este é um estudo tipo inquérito CAP (conhecimento, atitude e prática), realizado no período de fevereiro a junho de 2008, no qual se objetivou avaliar o conhecimento, a atitude e a prática do exame colpocitológico entre usuárias de uma unidade básica de saúde (UBS) e verificar sua associação com variáveis sociodemográficas. A amostra foi composta por 250 mulheres. O conhecimento, a atitude e a prática sobre o exame foram adequados em 40,4, 28 e 67,6\% das entrevistadas, respectivamente. Os resultados encontrados evidenciaram proporções mais altas de conhecimento e atitude adequados com escolaridade (>9 anos) e idade (>35 anos). É essencial buscar respostas específicas a respeito dessa problemática, a fim de direcionar ações integradas de educação em saúde, garantindo, assim, o maior acesso, adesão e retorno das mulheres ao exame.

Descritores: Conhecimentos, Atitudes e Prática em Saúde; Esfregaço Vaginal; Neoplasias do Colo do Útero; Enfermagem.

\section{Conocimiento, actitud y práctica relacionada al examen de colposcopia entre usuarias de una unidad básica de salud}

\begin{abstract}
Estudio tipo encuesta CAP (conocimiento, actitud y práctica) realizado en el período de febrero a junio de 2008, en el cual se objetivó evaluar el conocimiento, la actitud y la práctica del examen de colposcopia entre usuarias de una unidad básica de salud (UBS) y verificar su asociación con variables sociodemográficas. La muestra estuvo constituida por 250 mujeres. El conocimiento, la actitud y la práctica sobre el examen fueron adecuadas en $40,4 \%, 28 \%$ y $67,6 \%$ de las entrevistadas, respectivamente. Los resultados encontrados evidenciaron proporciones más altas de conocimiento y actitud adecuados con la escolaridad ( $>9$ años) y edad ( $>35$ años). Es esencial buscar respuestas específicas sobre esta problemática a fin de dirigir acciones integradas de educación en salud, garantizando, así, el mayor acceso, adhesión y retorno de las mujeres al examen.
\end{abstract}

Descriptores: Conocimientos, Actitudes y Práctica en Salud; Frotis Vaginal; Neoplasias del Cuello Uterino; Enfermería.

\section{Introduction}

Cervical cancer (CC) is a public health problem due to its high rates of prevalence and mortality in women of low social and economic levels and in the productive phase of their lives, indicating a strong association of this type of cancer with precarious living conditions, low indices of human development, the absence or weakness of community education strategies (health promotion and prevention) and with the difficulty of access to public health services for the early diagnosis and treatment of precursor lesions ${ }^{(1)}$.

In Brazil, without considering the non-melanoma skin cancers, CC is most incident disease in the Northern region (22/100.000). In the Southern (24/100.000),
Midwestern (19/100.000) and Northeastern $(18 / 100.000)$ regions it ranks as the second most frequent and in the Southeastern region (18/100.000) as the fourth(2). In 2008, 770 new cases of CC per 100,000 women were estimated for the state of Ceará(2), which, in relation to the Northeastern states of Brazil, ranked fifth in the number of cases estimated for 2008, with a rate of 17.8 cases/100,000 women. There are few studies on Papanicolau examination coverage in Brazil. The majority are concentrated in the major cities of the Southern and Southeastern regions of the country. The characteristics most frequently observed in women who did not undergo the cytopathological examination 
were: having a low socioeconomic level, low schooling, low household income, and belonging to younger age groups $^{(3)}$.

Research conducted with 141 women in a CC prevention service in the interior of the state of Ceará, revealed that the most cited reason, with 80 citations, for the search for consultations in order to perform a Papanicolau examination, was to present a complaint (vaginal discharge, pruritus, breast nodule, among others.), followed by the search for contraceptives $(n=36)$, the prevention of $C C(n=20)$ and the prenatal care routine $(n=05)^{(4)}$. In the same study, when the women were asked to name two prophylactic measures against CC, $97(68.8 \%)$ did not respond, while only 37 (26.2\%) cited the "cytology examination". The remainder reported the following measures: "caring for vaginal inflammation" $(n=3)$, "decrease in sexual relations and to avoid promiscuity" ( $n=5)$, "performance of vaginal cleanliness" $(n=3)$, "use of condoms" $(n=1)$, "not having sex while menstruating" $(n=1)$ and "not walking barefoot on hot ground" $(n=1)$. The total was greater than 141 citations, because 5 women cited more than one measure ${ }^{(4)}$. Assuming that this profile constitutes the reality of the clientele attended in the primary health units, it constitutes a population at risk for non-realization of the preventive examination and, among those who do perform it, for not returning to receive the examination results, the present investigation was developed with the aim of evaluating the knowledge, attitude and practice of the Pap smear test and to analyze the existence of associations with the demographic variables of the areas of residence of the research participants. Another factor that motivated this study was the finding, by a previous study, of a rate of approximately $25 \%$ of the performed Pap smear tests not being received by the service users studied(5). $^{(5)}$.

\section{Method}

This cross-sectional study was associated with the KAP (Knowledge, Attitude and Practice) investigation for the Pap smear test, conducted with women attending a primary health unit (PHU) located in a neighborhood on the outskirts of Fortaleza, in which five Family Health Strategy (FHS) teams have operated since August 2006, which covers a population of approximately 30,000 people. In this $\mathrm{PHU}$ the Pap smear test is carried out exclusively by nurses, in four sessions per week, with ten women per session and a mean of 102 examinations per month. In a pilot study, performed in January 2008, considering the rate of women who do not return to receive the result of the Papanicolau examination, in this institution, a rate of approximately $25 \%$ was identified $^{(5)}$.

The study population consisted of women who carried out the examination in the institution previously mentioned. The sample was calculated with an alpha error of 5\% (CI 95\%) and a beta error of $20 \%$ (power $80 \%$ ). Women who had commenced sexual activity and who attended the institution to perform the examination during the period of data collection were included in the sample. During the period, between February and June 2008, 250 women were interviewed about knowledge, attitude and practice regarding the Pap smear test. A structured form was used, consisting of pre-coded and open questions. In its preparation, questions from questionnaires used in other studies were used and

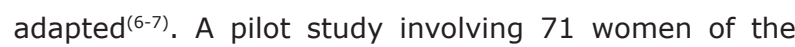
same institution, who did not participate in the main study, allowed adjustment of the instrument and of the process of data collection. Three interviewers were trained to administer the questionnaires.

Knowledge, attitude and practice regarding the Papanicolau examination were evaluated as follows:

Adequate knowledge - when the woman reported having heard about the examination, knew it was to detect cancer in general, or specifically of the cervix, and was able to cite at least two precautions necessary before performing the examination.

Inadequate knowledge - when the woman reported never having heard about the examination or had heard about it but did not know that it was to detect cancer; or was unable to cite at least two precautions that should be performed before the examination.

Adequate attitude - when the woman presented prevention of $\mathrm{CC}$ as a reason for performing the Papanicolau examination. When she reported as a reason the fact that it is a routine examination or a desire to know that she was in good health, an adequate attitude was only considered if she also had adequate knowledge about the examination.

Inadequate attitude - when the woman presented reasons for the examination other than the prevention of CC.

Adequate practice - when the woman had performed her last preventive examination within the previous three years; returned to receive the result of the last examination performed and sought a consultation to show the result of the examination.

Inadequate practice - when the woman had performed her last preventive examination more than 
three years before or had never taken an examination, even after having commenced sexual activity more than a year before; or when she had not returned to receive the last result; or had not sought a consultation to show the examination results.

The data were compiled and analyzed using the Statistical Package for the Social Sciences (SPSS) version 13.0 program. The association between adequacy of knowledge, of attitude and of practice of the examination and some socio-demographic characteristics, such as age, education, marital status, commencement of sexual intercourse, work outside the home, proximity of the residence to the health unit was analyzed using the Chi-square test, with a significance level of $5 \%$, to test differences between proportions.

Compliance with the regulations for research with human beings of Resolution 196/96 of the National Health Council of Brazil was ensured(8). The project was submitted to the Research Ethics Committee of the Federal University of Ceará - Walter Cantídio Hospital Complex and approved with the protocol number $283 / 07$. All participants were informed about the study objectives and, when in agreement, signed the terms of free prior informed consent, where they were guaranteed anonymity in the dissemination of the information and the freedom to participate, or not, in the study.

\section{Results}

Among the study participants, ages ranged between 14 and 71 years, with a mean age of 33.9 $(S D=12.7)$. The majority $(61.2 \%)$ of the women who performed the Pap smear test were aged 35 or younger. The mean age of commencing sexual intercourse was 16.9 years $(S D=3.2)$. In relation to the marital status of respondents, $65.6 \%$ lived with a partner. Most of the women $(80.7 \%$ ) had low schooling ( $\leq 9$ years), $62.8 \%$ did not work outside the home and $93.2 \%$ lived close to the PHU studied.

Regarding knowledge about the Pap smear test, only $40.4 \%$ were classified as having adequate knowledge. The majority of the respondents (98.4\%) reported having heard of the examination, but only $54.8 \%$ knew that the examination is to prevent CC. Among the other purposes of the examination mentioned, the one that stood out was to detect or prevent AIDS (42.1\%), followed by to detect wounds in the uterus/inflammation/scratches/leukorrhea (27.4\%) and to detect and prevent sexually transmitted diseases (STDs) (15.8\%) (Table 1).
Table 1 - Distribution of the study participants, according to the purposes of the Papanicolau examination cited. Fortaleza, Ceará, 2008

\begin{tabular}{lcc}
\hline \multicolumn{1}{c}{ Purposes of the examination } & N & \% \\
\hline To prevent cervical cancer & 137 & 54.8 \\
Do not know & 18 & 7.2 \\
Other purposes & 95 & 38.0 \\
To detect or prevent AIDS & 40 & 42.1 \\
To detect wounds in the uterus/inflammation/ & 26 & 27.4 \\
scratches & 15 & 15.8 \\
To detect or prevent STD & 08 & 8.4 \\
To detect or prevent leukorrhea diseases & 02 & 2.1 \\
To prevent pregnancy & 02 & 2.1 \\
To remove uterine growths & 01 & 1.1 \\
To detect fibroids & 01 & 1.1 \\
To prevent urinary infection & 95 & 100.0 \\
Subtotal & 250 & 100.0 \\
\hline Total
\end{tabular}

Also with reference to the evaluation of knowledge, women were asked to cite at least two precautions necessary before performing the examination. Of the 250 women, $12.0 \%$ were unable to cite any precautions and $32.6 \%$ reported only one. Among those who cited some precaution, the precaution most referred to was sexual abstinence $(66.7 \%)$ and the second was personal hygiene* $(30.1 \%)$. Only four $(1.6 \%)$ women mentioned the precaution of not using douches or vaginal creams (1.6\%).

Knowledge of the examination showed a statistically significant associated with some characteristics studied. Significantly greater proportions of adequate knowledge were identified among the women that were over 35 years of age, had more than nine years schooling, that lived with a partner and that worked outside the home. In addition, greater proportions of adequate attitude towards the examination were identified among the women that were over 35 years of age and had more than nine years of schooling. Higher percentages of adequate practice were observed among the women who live with a partner and lived near to the health clinic (Table 2).

In relation to the attitude of the women towards the examination, only $28 \%$ were classified as having an appropriate attitude. The majority (42.8\%) reported, as a reason for performing the examination, the fact that they were presenting some form of complaint. Conversely, only $10.0 \%$ cited the prevention of CC as a reason for performing the examination. Among the complaints most often cited were: pelvic pain $(33.0 \%)$, leukorrhea (15.1\%) and vulval itching (14.2\%).

* The precaution categorized as personal hygiene included the following reports of the women: pubic hair trimming, shaving, bathing, and others that did not include a vaginal douche. 
Table 2 - Evaluation of the percentage of adequate knowledge, attitude and practice regarding the Papanicolau examination, according to the characteristics studied. Fortaleza, Ceará, 2008

\begin{tabular}{|c|c|c|c|c|c|c|c|}
\hline \multirow{2}{*}{ Characteristics } & \multirow{2}{*}{ Total } & \multicolumn{2}{|c|}{ Adequate Knowledge } & \multicolumn{2}{|c|}{ Adequate Attitude } & \multicolumn{2}{|c|}{ Adequate Practice } \\
\hline & & $\mathbf{N}(\%)$ & p & N (\%) & p & $\mathbf{N}(\%)$ & p \\
\hline Age (years) & & & 0.020 & & 0.023 & & 0.132 \\
\hline$\leq 35$ & 153 & $53(34.6)$ & & $35(22.9)$ & & $98(64.1)$ & \\
\hline$>35$ & 97 & $48(49.5)$ & & $35(36.1)$ & & $71(73.2)$ & \\
\hline Schooling* (years) & & & 0.005 & & 0.020 & & 0.239 \\
\hline$\leq 9$ & 201 & $73(36.3)$ & & $50(24.9)$ & & $133(66.2)$ & \\
\hline$>9$ & 48 & $28(58.3)$ & & $20(41.7)$ & & $36(75.0)$ & \\
\hline Marital Status & & & 0.018 & & 0.226 & & 0.042 \\
\hline With partner & 164 & $75(45.7)$ & & $50(30.5)$ & & $118(72.0)$ & \\
\hline Without partner & 86 & $26(30.2)$ & & $20(23.3)$ & & $51(59.3)$ & \\
\hline Work Outside the Home & & & 0.005 & & 0.388 & & 0.381 \\
\hline Yes & 93 & $48(51.6)$ & & $29(31.2)$ & & $66(71.0)$ & \\
\hline No & 157 & $53(33.8)$ & & $41(26.1)$ & & $103(65.6)$ & \\
\hline Live close & & & 0.657 & & 0.893 & & 0.061 \\
\hline Yes & 233 & $95(40.8)$ & & $65(27.9)$ & & $161(69.1)$ & \\
\hline No & 17 & $06(35.3)$ & & $05(29.4)$ & & $08(47.1)$ & \\
\hline Commencement of sexual life (years) ${ }^{\star \star}$ & & & 0.106 & & 0.824 & & 0.241 \\
\hline$\leq 20$ & 214 & $82(38.3)$ & & $59(27.6)$ & & $142(66.4)$ & \\
\hline$>20$ & 34 & $18(52.9)$ & & $10(29.4)$ & & $26(76.5)$ & \\
\hline
\end{tabular}

* Lacking 1 (one) response

** 2 (two) did not respond

Regarding the practice of the examination, $67.6 \%$ were classified as having adequate practice. The majority $(72.8 \%)$ of the women interviewed referred to performing it at intervals not exceeding three years. It is interesting to observe that $85.2 \%$ of the women who were performing the examination for the first time and $75.0 \%$ of those who performed it at intervals greater than three years were classified as having inadequate knowledge, which showed a statistically significant relationship $(p=0.001)$. The women who perform the examination at intervals greater than three years also presented a higher proportion of non-return (12.5\%) to receive the last result, and $31.3 \%$ did not show the result to any professional (Figure 1 ).

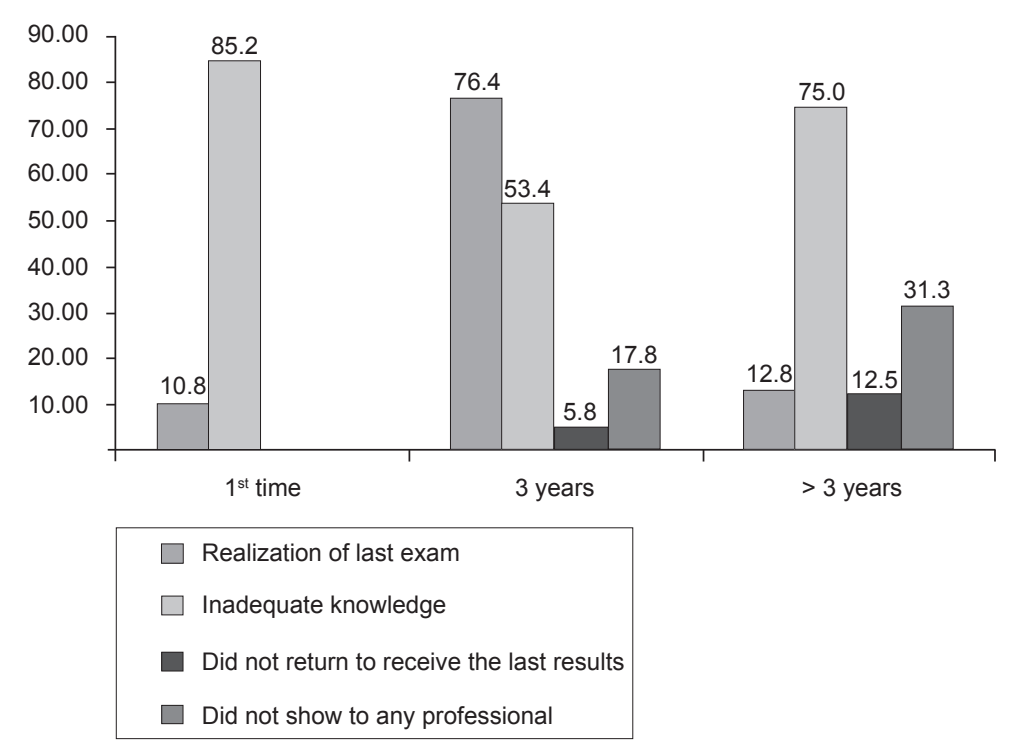

Figure 1 - Distribution of the women according to the variables periodicity, knowledge, return and presentation of the exam. Fortaleza, Ceará, 2008 
The findings of this study showed higher proportions of adequate knowledge and attitude in women who had more than nine years schooling and were over the age of 35 years, which was not the case for practice. The only factor associated with the adequate practice of the examination, found in this study, was marital status (with partner). The residence proximity in relation to the PHU and the age of commencement of sexual intercourse had no significant relationship with any of the variables studied. Higher proportions of adequate knowledge $(p<0.05)$, attitude $(p>0.05)$ and practice ( $p>0.05)$ regarding the Pap smear test were observed among women who worked outside the home.

Of the 250 women respondents, only 13 (5.2\%) reported not having returned to the unit to receive the last result. Of those who did not return, 12 (92.3\%) justified this behavior due to personal reasons. However, among the $208(83.2 \%)$ who returned, $17(8.17 \%)$ reported not having shown the examination to any professional, either due to personal problems $(41.2 \%)$ or due to institutional problems (58.8\%). Among the personal reasons reported by the women for not having returned to the unit to receive the result, the following were highlighted: "I changed my address" $(n=4)$, "because I did not" $(n=1)$, "I forgot" $(n=1)$, "my carelessness" $(n=1)$ and "I already received the medication on the day of consultation" $(n=1)$. Regarding the justifications for receiving the result, but not showing them to any professional, some of these were: personal - "I could not be bothered", "I forgot", "I was working", "I did not know I needed to show them" and institutional - "the employee left", "the result was not ready" $(n=9)$, "I could not get the form", "the clinic was on strike" and "there was no physician".

Personal reasons were those that contributed more to the women of this study not having returned to receive the result, being easily avoidable, according to the statements. However, among the factors cited to justify the fact that the examination results were not shown to a professional, institutional reasons prevailed. The institutional barriers cited by the women reveal the disorganization of the service and the difficult access to a follow-up consultation, which is performed only by physicians in this institution.

\section{Discussion}

The isolated offer of the examination for early detection of CC alone is not sufficient to reduce the mortality from this type of cancer among women. The favorable effect of the examination depends on this being correctly performed by the target population(9). Cervical cancer rarely affects women under 30 years of age, thus a priority age group for the systematic realization of the examination has been established as between 25 and 65 years of age. However, if the woman undergoes the examination only once in life, the ideal age is between 35 and 45 years of age(10). The most important risk factors associated with cervical cancer are: HPV infection, early commencement of sexual activity, multiple partners, low socioeconomic conditions, smoking, immunosuppression, inadequate personal hygiene and prolonged use of oral contraceptives ${ }^{(11)}$. Although it is often possible to identify the agent or the cytopathologic effects suggestive of the presence of STDs, the preventive examination is not intended to identify these. It is noteworthy that ectopia is a physiological situation, and therefore the terms "wound in the cervix" and "scratches" are inappropriate(11), as well as it being inadequate to say that the Pap smear test is used to detect them. During the study the fact that the women referred to the examination as a method of detection and prevention of AIDS was somewhat surprising. It is worrying to think that these women imagine themselves to be preventing AIDS through this examination, which reveals a deficit not only regarding knowledge about the Papanicolau examination, but also regarding the forms of detection and prevention of the AIDS virus.

It was evident that, although almost all of the respondents have heard about the Papanicolau examination, less than half of them (40.4\%) were classified with the factor adequate knowledge. These data are similar to those found in another study which evaluated the knowledge of the Papanicolau examination among Argentinean women(7). In addition to educating the population about preventing $\mathrm{CC}$, it is also important to explain the precautions that must be taken by women before undergoing the examination, for example: not using douches or intravaginal creams, avoiding sexual intercourse for 48 hours prior to the collection and not to be menstruating, since the neglect of these details interferes greatly in the realization of the examination, as well as in its result(11). In addition to the precautions cited above, the performance of personal hygiene before the examination, although not an obligatory precaution, facilitates the inspection of the external and internal genitalia by the examiner, and should be encouraged.

The fact that most of the women of the study lived near to the clinic was not related to the variable adequate knowledge about the examination $(p=0.657)$, 
which demonstrates the need to utilize the space of the waiting rooms of the health units with educational activities so that people can have access to accurate information and, thus, assume healthy behavior, as well being multipliers of this information. Although the women perceived the purpose of the Papanicolau examination, they considered it only an instrument for detection of gynecological disorders, and not a method of screening for the disease, which must be carried out mainly by those that are asymptomatic ${ }^{(12)}$. This causes many of them to seek the realization of the Papanicolau examination only when suffering from some sort of complaint $^{(4)}$, as was found in this study. It should be emphasized that the presence of vaginitis, discharges or colpocervicitis may compromise the interpretation of the cytopathology. The presence of an intense inflammatory process affects the quality of the sample. In such cases, the woman should be treated and return to carry out the preventive examination, as the treatment of inflammatory processes/STD decreases the risk of collecting unsatisfactory samples for analysis(11). The lack of knowledge in relation to the Pap smear test has been reported in the literature among the reasons cited by women for not performing the examination ${ }^{(12-13)}$. In another study, the fact that the women believed it is not necessary was the most frequently mentioned reason for not undergoing the examination ( $43.5 \%)$, followed by the reason of considering it an "embarrassing examination" $(28.1 \%)^{(14)}$. Lack of knowledge of the examination was reported by $5.7 \%$ of the women, and the difficulty in scheduling the examination by $13.7 \%$.

The Family Health Strategy (FHS), which has been adopted in Brazil as a model of primary health care, can contribute to overcoming existing barriers to the performance of the examination by identifying and encouraging, through the actions of health agents, the women who do not perform the examination. This program has as its principle the guarantee of access to primary care, the creation of bonds between the clientele and the health team and the integrality of care. As a result of these actions the promotion of knowledge is expected, as well as the valorization and the incorporation, by the population, of the preventive practices not only for $\mathrm{CC}$, but also for the other morbidities ${ }^{(15)}$. Some studies show a direct relationship between schooling and the practice ${ }^{(3,7)}$ and knowledge of the Papanicolau examination(7). Some studies confirm the factor low age, 15 to 24 years $^{(16)}$ and under $20^{(17)}$, to be associated with not performing the examination. However, in another study, there was no evidence of any relationship ${ }^{(7)}$.
The fact that almost all (85.2\%) the women who were carrying out the examination for the first time were classified as with inadequate knowledge about it highlights the importance of performing educational activities specific to these women, because in addition to having insufficient knowledge regarding the examination, they lack knowledge of the procedures related to it. In a study conducted in Fortaleza, with 326 women who did not return to get the result of the Papanicolau examination, 236 (72.4\%) were performing the examination for the first time ${ }^{(18)}$. Thus, it is for the professionals of the area to clarify the doubts and concerns of the clients and to emphasize that the prevention of $\mathrm{CC}$ is not limited simply to collecting material from the ectocervix and endocervix, but that it is only completed with the return of the client and the realization of appropriate treatment when necessary. A positive experience during the consultation can influence the return for the result and the realization of subsequent examinations ${ }^{(19)}$. This fact shows that it is vital to carry out educational activities focusing on the importance of the return in the prevention of CC, as well as the implementation of an active search service through the community health agents.

Some studies have revealed a similar situation in other areas surveyed. In a study conducted in a PHU in Fortaleza, the main reasons cited by the women for not having returned were: the work situation of the woman, the financial and travel difficulties, the lack of adequate guidance from professionals regarding the need to return, difficulties in changing the return date, as well as the long wait to schedule a consultation and reduced material and human resources(20). Conversely, some women, in this same study, presented as a justification, problems that are easily resolved for not having attended the followup consultation, and even then, did not seek any other alternative. Such behavior leads to the questioning of the importance given by these women to the examination, in view of the follow-up consultation being scheduled one month in advance, allowing, through this, the women to adequately plan their attendance at the service. This situation complicates the monitoring, integrity and continuity of care, contributing to the persistence of a serious problem in this area, which is the intervention at later stages of the disease. It is essential to change the condition of coverage of the examinations in relation to the Brazilian women who still do not have access to this procedure, however, the structure and quality of services that offer the examination today, which do not provide integral assistance to the woman in order to effectively combat CC must also be considered. 


\section{Final considerations}

The users of the primary health unit studied presented high proportions regarding the factor of inadequate knowledge and attitude compared to the practice, which reveals that they practice the examination within the criteria established as adequate, without knowing what it is for or even without the correct motivation to do so. These results can be explained by the fact that there are not, in the health unit studied, educational activities on the topic. Here, the importance of health education as a means of achieving effective results in the control of gynecologic cancer is highlighted. The nurse is a professional who has assumed the implementation of the Pap smear test in the primary care, yet the distancing of this professional from educational activities has become apparent, to the detriment of the consultations, which is alarming for the profession.

Numerous factors may be associated with the deficiency found in the knowledge, attitude and practice of women in relation to the Papanicolau examination, making it essential to search for specific answers regarding this issue, in order to direct integrated actions of health education, to strengthen the care provided and to ensure greater accessibility and adhesion of the women, both to the examination and to the follow-up appointment, for the prevention of CC.

\section{References}

1. Ministério da Saúde (BR). Secretaria de Atenção à Saúde. Instituto Nacional de Câncer. Coordenação de Prevenção e Vigilância. Nomenclatura brasileira para laudos cervicais e condutas preconizadas: recomendações para profissionais de saúde. Rio de Janeiro (RJ): INCA; 2006.

2. Ministério da Saúde (BR). Secretaria de Atenção à Saúde. Instituto Nacional de Câncer. Coordenação de Prevenção e Vigilância de Câncer. Estimativas 2008: Incidência de Câncer no Brasil. Rio de Janeiro (RJ): INCA; 2007.

3. Martins LFL, Thuler LCS, Valente JG. Cobertura do exame de Papanicolaou no Brasil e seus fatores determinantes: uma revisão sistemática da literatura. Rev Bras Ginecol Obstet. 2005;27(8):485-92.

4. Santos MCL, Fernandes AFC, Cavalcante PP. Consulta ginecológica - Motivações e conhecimento da mulher sobre a prevenção do câncer do colo do útero. Rev RENE. 2004; 5(1):22-6.

5. Vasconcelos CTM, Vasconcelos Neto JA, Castelo ARP, Medeiros FC, Pinheiro AKB. Análise da cobertura e dos exames colpocitológicos não retirados de uma Unidade Básica de Saúde. Rev Esc Enferm USP. 2010;44(2):324-30.

6. Brenna SMF, Hardy E, Zeferino LC, Namura I. Conhecimento, atitude e prática do exame de Papanicolaou em mulheres com câncer de colo uterino. Cad Saúde Pública. 2001;17(4):909-14.

7. Gamarra CJ, Paz EPA, Griep RH. Conhecimentos, atitudes e prática do exame de Papanicolaou entre mulheres argentinas. Rev Saúde Pública. 2005;39(2):270-6.

8. Ministério da Saúde (BR). Conselho Nacional de Saúde. Resolução n.o 196/96. Diretrizes e normas regulamentadoras da pesquisa envolvendo seres humanos: Brasília (DF): Ministério da Saúde; 1996. [acesso 10 maio 2007]. Disponível em: http:// www. ufrgs.br/hcpa/gppg/res19696.htm.

9. Isla V. Cáncer cérvico-uterino: el cancer que no debe matar. Agenda Salud. 2002;(25):1-8.

10. Organización Mundial de la Salud. Control integral del cáncer cervicouterino: guía de práticas esenciales. Genebra: OMS; 2007.

11. Ministério da Saúde (BR). Controle dos cânceres do colo do útero e da mama. Brasília (DF): Ministério da Saúde; 2006.

12. Pinnoti JA. Saúde da mulher. São Paulo: Parâmetro; 1996.

13. Gesteira SMA, Lopes RLM. Ano 2000 ... e o câncer cérvico-uterino ainda é um problema de saúde pública no país. Rev Baiana Enferm. 2000;13(1/2):93-101.

14. Amorim VMSL, Barros MBA, César CLG, Carandina L, Goldbaum M. Fatores associados à não realização do exame de Papanicolaou: um estudo de base populacional no Município de Campinas, São Paulo, Brasil. Cad Saúde Pública. 2006;22(11):2329-38.

15. Coughlin SS, Uhler RJ. Breast and cervical screening practices among Hispanic women in the United States and Puerto Rico, 1998-1999. Prev Med. 2002;34:242-51.

16. Nascimento CM, Eluf-Neto J, Rego RA. Pap test coverage in São Paulo municipality and characteristics of the women tested. Bull Panam Health Organ. 1996;30(4):302-12.

17. Cesar JA, Horta BL, Gomes G, Houlthausen RS, Willrich RM, Kaercher $A$, et al. Fatores associados à não realização de exame citopatológico de colo uterino no extremo Sul do Brasil. Cad Saúde Pública. 2003;19(5):1365-72.

18. Victor JF, Moreira TMM, Araújo AR. Exames de prevenção de câncer de colo uterino realizados e não retirados de uma Unidade Básica de Fortaleza - Ceará. Acta Paul Enferm. 2004;17(4):407-11. 
19. Ministério da Saúde (BR). Manual técnico: prevenção do câncer de colo uterino. Brasília (DF): Ministério da Saúde; 2002.

20. Greenwood AS, Machado MFAS, Sampaio NVV. Motivos que levam as mulheres a não retornarem para receber o resultado do exame de Papanicolaou. Rev. Latino-Am. Enfermagem. 2006;14(4):503-9. 